\title{
Techniques for Ensuring Fault Ride-Through Capability of Grid Connected DFIG-Based Wind Turbine Systems: A Review
}

\author{
M. Shuaibu ${ }^{1 *}$, A. S. Abubakar ${ }^{1}$, A. F. Shehu ${ }^{2}$ \\ ${ }^{1}$ Department of Electrical Engineering, Ahmadu Bello University, Zaria, Nigeria. \\ ${ }^{2}$ Katsina State Institute of Technology and Management, Katsina, Nigeria.
}

\begin{abstract}
Renewable energy sources (RES) are being integrated to electrical grid to complement the conventional sources to meet up with global electrical energy demand. Among other RES, Wind Energy Conversion Systems (WECS) with Doubly Fed Induction Generator (DFIG) have gained global electricity market competitiveness because of the flexible regulation of active and reactive power, higher power quality, variable speed operation, four quadrant converter operation and better dynamic performance. Grid connected DFIG-based WECS are prone to disturbances in the network because of direct connection of stator windings to grid. The ability of the Wind Turbine (WT) to remain connected during grid faults is termed the Fault Ride-Through (FRT) capability. The grid code requirement for integrating the DFIG-based WTs to power networks specified that they must remain connected and support the grid stability during grid disturbances of up to $1500 \mathrm{~ms}$. The use of compensation devices offers the best FRT compliance thereby protecting the DFIG and the converters from voltage fluctuations and over currents during the grid fault. The paper presents a review of techniques employed in ensuring FRT compliance. The article also proposes the state-ofthe-art techniques for compensating voltage sag/swell and limiting the fault short-circuit current.
\end{abstract}

KEYWORDS: Renewable energy sources, DFIG, wind turbine system, fault ride-through, grid codes, dual-functional DVR

[Received Jul. 10, 2020; Revised Dec. 28, 2020; Accepted Feb. 13, 2021]

Print ISSN: 0189-9546 | Online ISSN: 2437-2110

\section{INTRODUCTION}

Concerns about global warming and depleting fossil fuels gave rise to the intense venture to Renewable Energy Sources (RES) like solar, wind, geothermal, tidal energy sources etc. As at January 2018, about 25\% of world power generation came from renewable energy sources (Pioro et al., 2019). Of the RES highlighted above, wind energy became more prominent with 450GW capacity in 2016 (Giddey et al., 2019). Wind power generation capacity is now competing with the conventional sources in 83 countries out of which 24 have more than 1GW generation capacity (Esch, 2015). Thus, the number of Wind Turbine systems connected to grid has increased from $227 \mathrm{GW}$ in 2015 to about $350 \mathrm{GW}$ in 2017 (Karakasis et al., 2018).

The Electrical energy generation using WT is achieved using different configurations based on synchronous or induction generators (Gardner et al., 2012). The common generators used for WT systems are the Doubly Fed Induction Generator (DFIG), Permanent Magnet Synchronous Generator (PMSG), Squirrel Cage Induction Generator (SCIG) and Brushless Doubly Fed Induction Generator (BDIG). DFIG is the most popular due to advantages like the reduced mechanical stress on the WT, low power rating of the connected power electronics converters, flexible regulation of active and reactive power, higher power quality and variable *Corresponding author: smusayyibi@abu.edu.ng speed operation (Amalorpavaraj et al., 2017; Gardner et al., 2012; Karakasis et al., 2018; Shehu et al., 2019; Yang et al., 2012; Yaramasu et al., 2015).

However, the major disadvantage of grid connected DFIG-based WT is that increasing the performance of DFIG by flux weakening control method is very difficult because of the direct connection of the stator to the grid (Karakasis et al., 2018). In this configuration, the stator flux is directly controlled by the grid voltage. Voltage dip will result in a sudden change of machine magnetization thereby producing a current surge in the Rotor Side Converter (RSC) (Zhu et al., 2017). This surge current is generally large and without suitable control strategy and it may cause damage to the converters. Therefore, appropriate control strategy must be employed to ride through low voltage faults (Long et al., 2013). The ability of the WT to stay connected to the grid during grid faults is termed as Fault Ride-Through (FRT) capability (Yang et al., 2012).

This paper presents a comprehensive review of articles that presented research works on FRT capability of DFIG Based WT with the view of giving insight into the limitations of the techniques and proposition of a technique that incorporates fault current limiting capability into the FRT. 


\section{FAULT RIDE-THROUGH}

Fault Ride-Through (FRT) capability refers to ability of WT to withstand transient disturbances during severe system or grid faults. WT are expected to work during short duration faults and support grid stability. This requirement is very difficult to attain using DFIG control because of rotor mass moment of inertia (Gardner et al., 2012).

\section{A. Composition of fault ride-through}

FRT comprises of all the three voltage deviation profiles as Voltage Ride-Through (VRT) highlighted in (i) - (iii) as follows (Yaramasu et al., 2015):

i. Zero Voltage Ride-Through (ZVRT) - when grid voltage is zero;

ii. Low Voltage Ride-Through (LVRT) - when grid voltage is between $(15-25) \%$ and

iii. High-Voltage Ride-Through (HVRT) - when there is over voltage of up to $120 \%$ of nominal value.

\section{B. Grid Code Requirements}

The general requirements based on technical features of power systems are categorized as (i) tolerance; (ii) control of reactive power; (iii) control of active power; (iv) protection and (v) power quality (Gardner et al., 2012). In order to sustain the grid connected WT systems, most countries set wind power grid connection codes which require that WTs should remain connected to the grid for the purpose of sustaining the overall system reliability (Yang et al., 2012). According to grid codes depicted in Figure 1, whenever grid experiences low voltage faults, WT system need to ride through a period of up to 150 $\mathrm{ms}$ and a recovery period of up to 1.35 seconds; and inject up to rated current of the reactive current to the grid during the entire low voltage fault time (Long et al., 2013). The revised grid codes require that WTs must also provide reactive power during the faults (Zhu et al., 2017).

The recent grid codes adopted by several countries are aimed towards achieving a better FRT capability. The requirements are as follows (Ambati et al., 2015):

1. WT must stay connected to the grid for a certain time (determined by the system specifications);

2. Active power must be restored immediately after the fault clearance; and

3. WT must provide reactive power thereby supporting the grid voltage during the fault.

The FRT profile according to E.ON (Greek, aeon) an European utility company's regulation is shown in Figure 1 with ZVRT, LVRT and HVRT requirements illustrated. Essentially, the FRT operation must be accomplished within $200 \mathrm{~ms}$ whenever grid voltage falls below $0.9 \mathrm{pu}$. However, if the grid voltage is between 0.9-0.5 pu, the DFIG should provide $2 \%$ reactive current for corresponding $1 \%$ voltage drop and if the voltage falls below $0.5 \mathrm{pu}$ then the system should provide $100 \%$ reactive current.

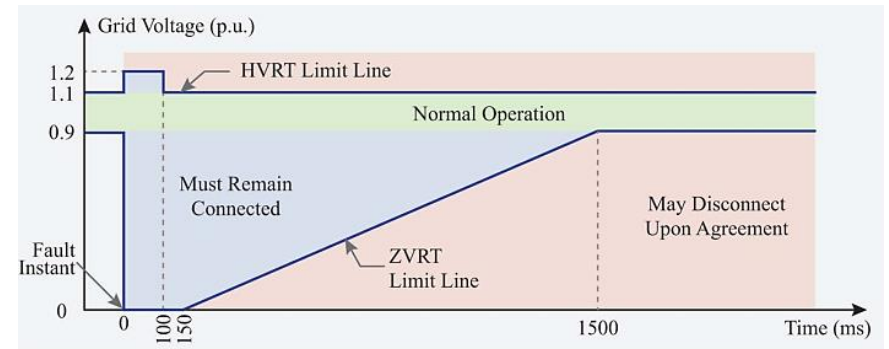

Figure 1: VRT Requirements According to E.ON Regulation (Yaramasu et al., 2015).

III. DFIG - BASED WIND TURBINE SYSTEM

DFIG-based WT system essentially consists of WT with drive train system, DFIG and accessories, pitch controller, coupling transformer and protective devices (Ganesh and Rani, 2013). The DFIG is basically a Wound Rotor Induction Generator (WRIG) with slip rings whose stator is directly connected to the grid while the rotor interfaced via a partially rated variable frequency (ac-dc-ac) converter (VFC). The VFC comprises of a Rotor Side Converter (RSC) and Grid Side Converter (GSC) connected back-to-back by a dc-link capacitor (Ibrahim et al., 2011). A typical structure of DFIGbased WT is shown in Figure 2.

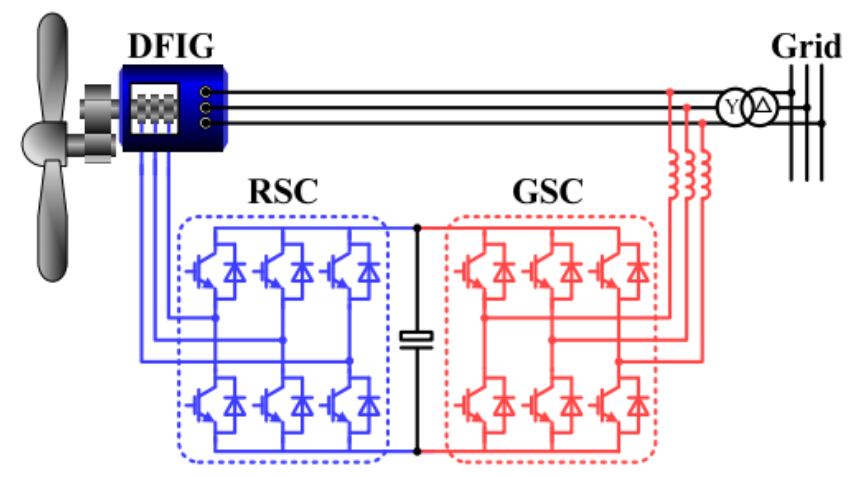

Figure 2: Structure of DFIG-based Wind Turbine (Zhu et al., 2017).

\section{A. Model of a DFIG-based WT}

The dynamic model of the of WT system is achieved by aggregating torque and pitch actuator system, aerodynamic model, shaft subsystem, tower and DFIG model as depicted in Figure 3.

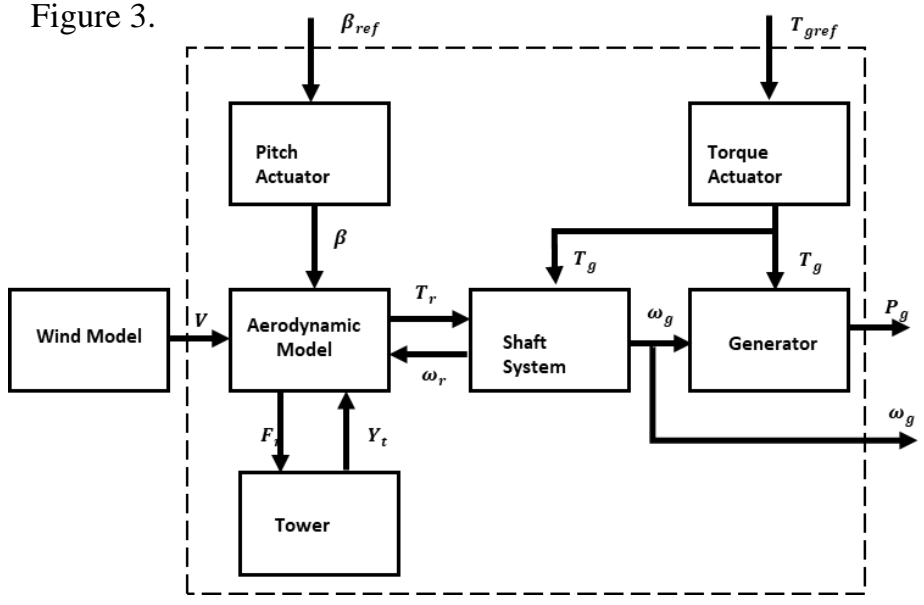

Figure 3: Components of DFIG-Based Wind Turbine System (Abubakar, 2019). 
Wind energy is captured by the blades of the WT and converted to rotational kinetic energy. The WT speed value determines the values and control methods for converters, torque, and pitch. The aerodynamic equation of turbine gives the power generated $P_{m}$ which is expressed as equation 1 (Sitharthan et al., 2018)

$$
P_{m}=0.5 \rho C_{p}(\lambda, \beta) A W^{3}
$$

Where $\rho$ is the air density of approximate value of $1.225 \mathrm{~kg} / \mathrm{m}^{3}, C_{p}$ is the Betz's Coefficient, $\lambda$ is tip-speed ratio, $\quad \beta$ is pitch angle, $\mathrm{A}$ is the swept area of the blades in $\mathrm{m}^{2}$ and $\mathrm{W}$ is the variable flow of wind speed in $\mathrm{m} / \mathrm{s}$.

The WT performance coefficient, $C_{p}(\lambda, \beta)$ relates the tackled power by the WT in percentage of the maximum kinetic energy potential from the wind. It ensures the maximization of power from WT (Agalar and Kaplan, 2018). It is expressed as equation 2 (Sitharthan et al., 2018)

$$
C_{p}(\lambda, \beta)=0.52\left(\frac{116}{\lambda_{j}}-0.4 \beta-5\right) e^{-\frac{2 I}{\lambda_{j}}}+0.0066 \lambda
$$

$C_{p}(\lambda, \beta)$ given as function of $\lambda_{j}$ and $\beta$ (the pitch angle of the system in degrees). The relationship between the tip-speed ratio $(\lambda)$ and swept area radius of the WT $(R)$ is given by equaton 3 (Sitharthan et al., 2018).

$$
\lambda=\frac{\omega_{r}{ }^{*} R}{W}
$$

The mechanical torque input to the DFIG though gear shaft is given by equation 4 :

$$
T_{m}=\frac{0.5 \rho C_{p}(\lambda, \beta) A W^{3}}{\omega_{r}}
$$

The value of $C_{p}(\lambda, \beta)$ depends on empirical values obtained from experiments. However, the speculative value of $C_{p}$ is limited to 0.593 as described by Betz's law and a typical value of $C_{p}$ is 0.532 for wind turbines operated in the low speed region as in the work of (Abubakar et al., 2018). According to (Bhandare et al., 2013), different wind speed generates distinct power, leading to different curves of $C_{p}$ in graph showing the correlation between power output and wind speed.

\section{B. Concept and Mode of DFIG}

The DFIG is a wound rotor induction machine with both stator and rotor winding going to electrical sources - thus the term 'doubly fed'. The dynamic model of DFIG is based on generalized machine model in synchronous reference frame together with the system parameters and variables in per unit (p.u) as referred to the stator side (Rahimi and Parniani, 2010). Figure 4 shows the equivalent circuit of the DFIG in synchronous $d q$ reference frame.

The dq voltage and flux equations of the equivalent circuit of DFIG are as follows.

$$
\begin{aligned}
& v_{d s}=R_{s} i_{d s}+\frac{d \lambda_{d s}}{d t}-\omega_{e} \lambda_{q s} \\
& v_{q s}=R_{s} i_{q s}+\frac{d \lambda_{q s}}{d t}+\omega_{e} \lambda_{d s} \\
& v_{d r}=R_{r} i_{d r}+\frac{d \lambda_{d r}}{d t}-\left(\omega_{e}-\omega_{r}\right) \lambda_{q r} \\
& v_{q r}=R_{r} i_{q r}+\frac{d \lambda_{q r}}{d t}+\left(\omega_{e}-\omega_{r}\right) \lambda_{d r}
\end{aligned}
$$

(Amalorpavaraj et al., 2017):
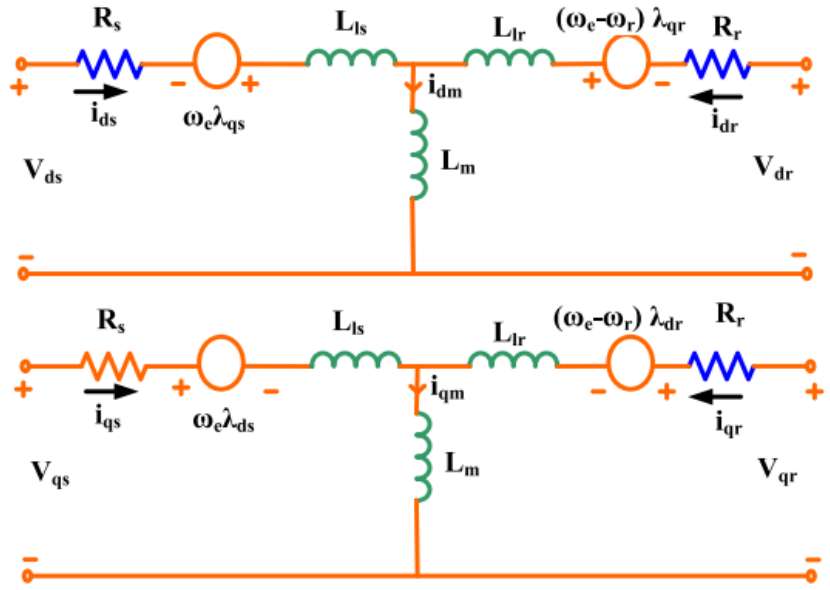

Figure 4: Equivalent Circuit of DFIG (Alaraifi et al., 2013).

where the subscripts $d s$ and $q s$ represent the $\mathrm{d}$ and $\mathrm{q}$ components of stator and $d s$ and $q r$ represent the $\mathrm{d}$ and $\mathrm{q}$ components of rotor respectively, $\omega$ and $\lambda$ represent angular frequency and flux linkage, respectively.

If $L_{s}$ and $L_{r}$ represent the stator and rotor inductance respectively, then the stator and rotor side inductances can be obtained using:

$$
\begin{gathered}
L_{s}=L_{l s}+L_{m} \\
L_{r}=L_{l r}+L_{m}
\end{gathered}
$$

Where $L_{l s}$ and $L_{1 r}$ are the stator and rotor leakage inductance respectively and $L_{m}$ is the magnetizing inductance. The flux linkage equations for both stator and rotor are given by

$$
\begin{aligned}
& \lambda_{d s}=L_{s} i_{d s}+L_{m} i_{d r} \\
& \lambda_{q s}=L_{s} i_{q s}+L_{m} i_{q r} \\
& \lambda_{d r}=L_{m} i_{d s}+L_{r} i_{d r} \\
& \lambda_{q r}=L_{m} i_{q s}+L_{r} i_{q r}
\end{aligned}
$$

The real power $\left(P_{S}\right)$ and reactive power $\left(Q_{s}\right)$ generated by DFIG are given by

$$
\begin{aligned}
& P_{s}=\frac{3}{2}\left(v_{q s} i_{q s}+v_{d s} i_{d s}\right) \\
& Q_{s}=\frac{3}{2}\left(v_{q s} i_{d s}-v_{d s} i_{q s}\right)
\end{aligned}
$$

(Jibril et al., 2019)

\section{Operating Principle of DFIG}

The analysis of DFIG operation while at steady and transient conditions is vital to understanding its behavior during grid faults. The fault analysis is necessary for the implementation of FRT capability (Amalorpavaraj et al., 2017).

The stator of DFIG is connected directly to grid while the rotor is connected to the grid via slip rings through a partialscale back-to-back power converter. The back-to-back converter has a Rotor Side Converter (RSC) and Grid Side Converter (GSC) connected by a dc-link. The dc-link is a capacitor serving as energy storage and serving as dc-link voltage variations or ripples limiter. The converter handles about $20-30 \%$ of total power generated and also controls torque, speed together with reactive power from or to the grid (Alsmadi et al., 2018). The rotor three-phase windings are energized with three-phase current supplied by the RSC. As such, the rotor and stator magnetic field interacts to develop 
torque which is a vector product of the two vector fields (Fletcher and Yang, 2010).

\section{Control of DFIG}

The control of DFIG is mainly to regulate the power extracted from the WT; limit the power during high wind speeds; and to regulate the exchange of reactive power between the WT system and the grid (Chen et al., 2009). The control entails pitch control for the turbine, RSC and GSC control for the DFIG (Ganesh and Rani, 2013). The RSC is controlled by the rotor current. In the process, RSC controls the torque and excitation of the DFIG. Also, the GSC ensures constant dc-link voltage is maintained within the allowable limit (Alsmadi et al., 2018; Jibril et al., 2019). Figure 5 shows the control block diagram of DFIG. Most DFIGs employs close-loop current control employing Voltage Source Inverter (VSI) or vectorcontrol technique.

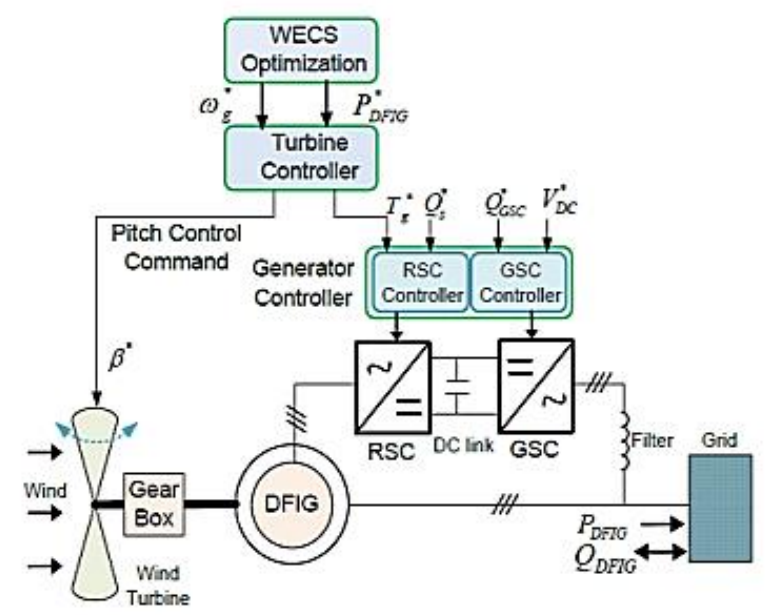

Figure 5: Control Block Diagram of DFIG-based WT (Ganesh and Rani, 2013).

\section{F. Behavior of DFIG during Grid Fault}

Generally, faults in power system are categorized as series and shunt faults. The commonest faults in power system are shunt faults involving power conductor or conductors-toground or short circuit between conductors. Shunt faults are characterized by increase in current and fall in voltage and frequency (Kothari and Nagrath, 2008).

The stator flux $\left(\lambda_{s}\right)$ rotates at constant magnitude proportional to the grid voltage and at synchronous speed $\left(N_{s}\right)$ during normal operation. The occurrence of grid fault drops voltage extremely at the generator terminal because of the direct connection of stator winding to the grid. According to the constant flux leakage principle, the stator flux cannot react to the voltage drop instantly (Ambati et al., 2015). Consequently, dc voltages are produced in the stator windings. The dc component of stator voltage is proportional to the severity of the fault. This dc voltage component of the stator changes the slip of the DFIG to about 20\% (Ambati et al., 2015; Sitharthan et al., 2018).

The voltage drop reduces active power generation resulting to sharp increase in rotor current to compensate the active power by RSC. Consequently, the converter increases the rotor voltage and an overvoltage in the DC-link. However, the maximum values of rotor current and dc-link voltage are critical to guarantee effective FRT capability (Amalorpavaraj et al., 2017).

Figure 6 shows the dynamic behavior of stator flux during fault. It can be deduced from the figure that the flux vector:

i. Rotates about outer circle during normal operations.

ii. Divides into the dc component about OO' and ac synchronous component AO'.

iii. The ac component offsets the dc part and decay naturally along point B immediately after the fault (Alsmadi et al., 2018).

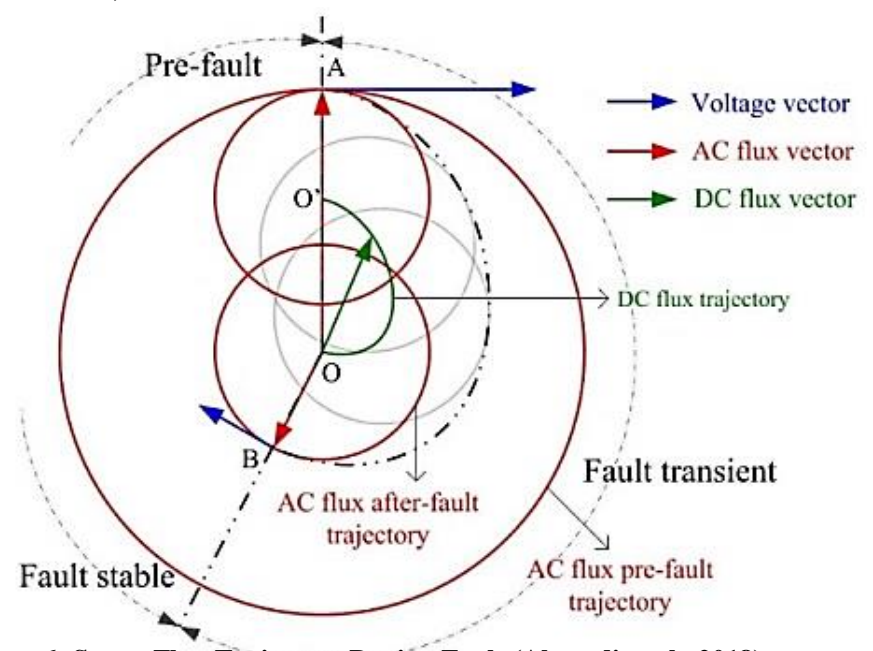

Figure 6: Stator Flux Trajectory-During Fault (Alsmadi et al., 2018).

The inrush current in rotor as a result of fault increases the active power and the dc-link capacitor voltage. These lead to dangerous pulsating electromagnetic torque oscillation thereby damaging the DFIG (Sitharthan et al., 2018).

\section{TECHNIQUES FOR ENSURING FRT COMPLIANCE}

Several approaches were proffered to ensure FRT capability of DFIG-based WTs. The approaches are categorized under crowbar, storage of surplus energy, pitch control system and compensation techniques. The pitch angle control response is very slow due to DFIG's large moment of inertia. Although an advanced control technique like Robust Model Predictive Controller (RMPC) for MPPT was developed by (Abubakar, 2018), it only improves the response time for the MPPT and reduce the time for the ride-through. Second-order sliding mode control for DFIG-based WT FRT capability enhancement was presented in (Benbouzid et al., 2014). These methods must be used alongside other FRT enhancement methods for better capability. The grid code requirements made the crowbar method of protecting the converters from flow of rotor over-currents during faults obsolete (Amalorpavaraj et al., 2017). Crowbar operation disables and short-circuits the RSC, making the DFIG to act like Squirrel Cage Induction Generator (SCIG) thereby absorbing reactive power instead of supporting the grid (Zhu et al., 2017).

Other techniques developed which addresses the limitations of using crowbars are the protection using Series Grid Side Converter (SGSC), Dynamic Resistor, connection of Distribution Static Synchronous Compensator (DSTATCOM) 
at the Point of Common Coupling (PCC) as discussed by (Amalorpavaraj et al., 2017; Ambati et al., 2015; Wessels et al., 2011; Zhu et al., 2017). However, DSTATCOM operation ignores fast variations in voltage source and as such it cannot protect the RSC from over current and therefore require the addition of crowbar protection (Amalorpavaraj et al., 2017;Padiyar, 2007).

The use of compensation devices together with surplus energy storage protects the DFIG and the converters from the effects of voltage fluctuations during grid fault (Shuaibu and Abubakar, 2020; Yaramasu et al., 2015). The compensation device commonly used is the Dynamic Voltage Restorer
(DVR) while Superconducting Fault Current Limiter (SFCL) is mostly used as the surplus energy storage device. The operation of DVR is based on series voltage technique whereby a series injection transformer combines with Voltage Series Inverter (VSI), filter, DC capacitor and energy storage is connected at PCC. The control of DVR are based on three basic strategies - pre-sag compensation, in-phase compensation and minimum energy compensation (Padiyar, 2007).

Various methods and technologies for ensuring FRT capabilities of DFIG WT and other RES systems are summarized in Figure 7 by (Tarafdar Hagh and Khalili, 2019).

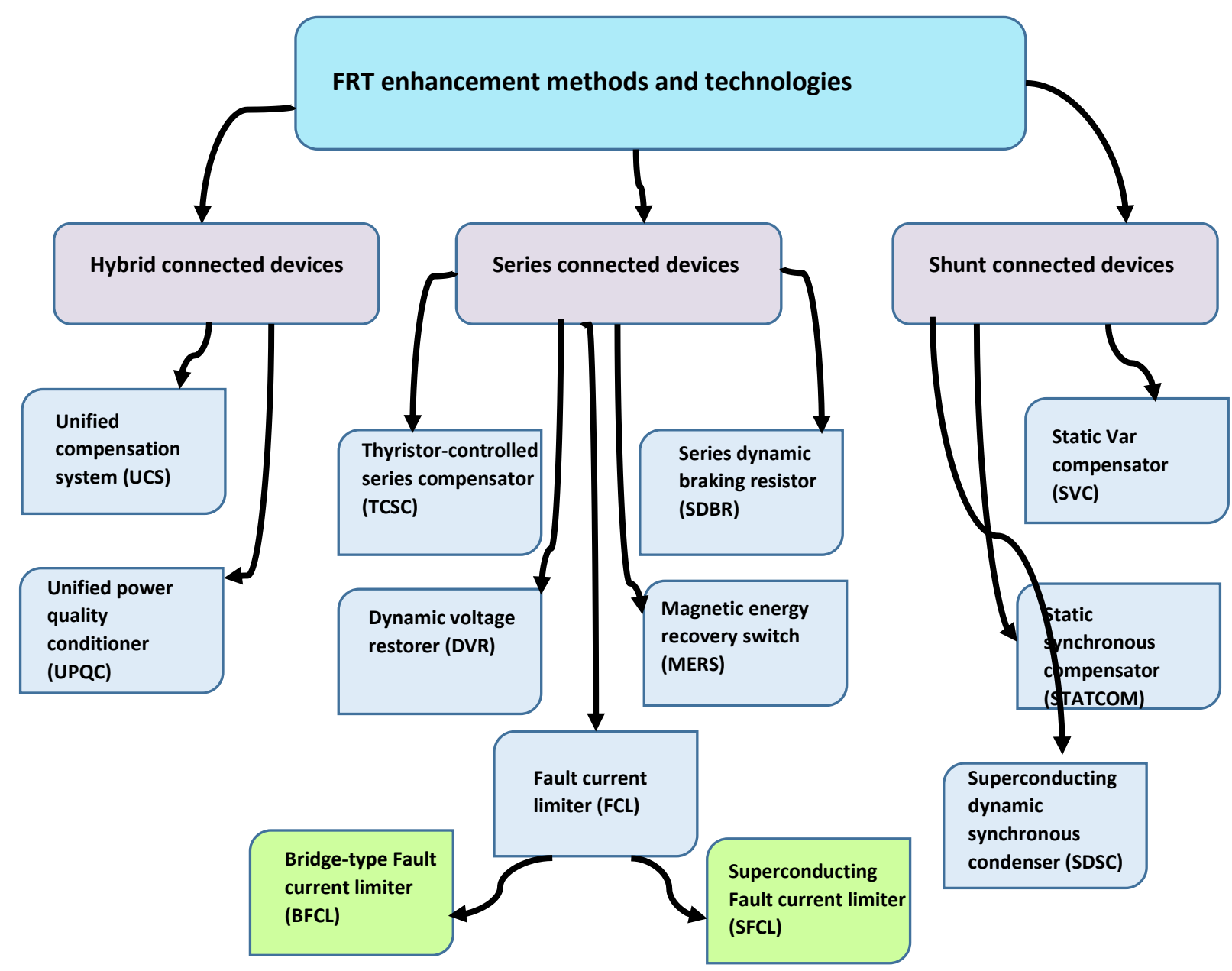

Figure 7: FRT Enhancement Methods and Technologies (Tarafdar Hagh \& Khalili, 2019).

\section{A. Review of Papers that Presented Techniques}

Table 1 shows a review of works on surplus energy, compensation device configurations and techniques employed for better FRT of DFIG based WT systems with their limitations. 


\section{Table 1: Review of Papers that Presented FRT Capability Techniques}

\begin{tabular}{|c|c|c|c|}
\hline $\mathbf{S} / \mathbf{N}$ & Work & Contribution & Limitation (s) \\
\hline 1. & $\begin{array}{l}\text { Ganesh and Rani, } \\
\text { (2013) }\end{array}$ & $\begin{array}{l}\text { FRT capability enhancement scheme using DVR with SPWM } \\
\text { technique for switching the VSI of the DVR; PI controller for } \\
\text { processing the error between reference and rms values of the } \\
\text { DFIG terminal voltage. }\end{array}$ & $\begin{array}{l}\text { i. No indication of the maximum duration of the } \\
\text { operation of DVR } \\
\text { ii. No reactive power support. }\end{array}$ \\
\hline 2. & $\begin{array}{l}\text { Elshiekh et al., } \\
\text { (2013) }\end{array}$ & $\begin{array}{l}\text { Use SFCL connected to the stator side of the grid to reduce } \\
\text { stator fault current. It improves FRT by absorbing fault current } \\
\text { thereby preventing the stator from voltage dips. }\end{array}$ & i. Cannot handle severe and prolonged fault. \\
\hline 3. & $\begin{array}{l}\text { Ngamroo and } \\
\text { Karaipoom, (2014) }\end{array}$ & $\begin{array}{l}\text { Employed Superconducting Magnetic Energy Storage with } \\
\text { Fault Current Limiting (SMES-FCL) function. SC inductance } \\
\text { in series with the grid was optimized to reduce fault current } \\
\text { during severe grid faults }\end{array}$ & $\begin{array}{l}\text { i. Not suitable in handling dangerous } \\
\text { electromagnetic torque pulsation. }\end{array}$ \\
\hline 4. & $\begin{array}{l}\text { Ambati et al., } \\
(2015)\end{array}$ & $\begin{array}{l}\text { Worked on low component Series Voltage Compensation } \\
\text { (SeVC) scheme with coordinated control strategy to replace } \\
\text { additional series transformer and VSC for compensation }\end{array}$ & $\begin{array}{l}\text { The presence of negative sequence at PCC can lead } \\
\text { to oscillations in dc-link voltage thus, the system } \\
\text { stability is not guaranteed. }\end{array}$ \\
\hline 5. & Chen et al., (2015) & $\begin{array}{l}\text { Proposed a voltage compensation type active SFCL. The } \\
\text { model suggested a method of limiting fault current through } \\
\text { stator and rotor windings thus maintaining the DFIG terminal } \\
\text { voltage. }\end{array}$ & $\begin{array}{l}\text { i. Incurs electromagnetic torque oscillation } \\
\text { ii. The 3-phase 4-wire converter make the method } \\
\text { ineffective for asymmetrical fault. }\end{array}$ \\
\hline 6. & Shen et al., (2015) & $\begin{array}{l}\text { Presented a transient reconfiguration solution and coordinated } \\
\text { control strategy for power converters to enhance FRT. RSC is } \\
\text { equipped with Electric Double-Layer Capacitor (EDLC)-based } \\
\text { Energy Storage Device (ESD) to regulate dc-link voltage. }\end{array}$ & $\begin{array}{l}\text { The large value of rotor mass inertia reduces the } \\
\text { time response of the scheme }\end{array}$ \\
\hline 7. & Zhu et al., (2015) & $\begin{array}{l}\text { Presented a virtual damping flux-based LVRT control. It } \\
\text { investigated the suppression of rotor current using virtual } \\
\text { damping flux strategy. }\end{array}$ & $\begin{array}{l}\text { The compensation method only reduces the } \\
\text { amplitude of electromagnetic torque and reactive } \\
\text { power oscillation ripples but did not eliminate } \\
\text { them. }\end{array}$ \\
\hline 8. & Pawar et al., (2016) & $\begin{array}{l}\text { Improvement of LVRT capability considering wind speed } \\
\text { variation, pitch control for the selection of crowbar size. }\end{array}$ & $\begin{array}{l}\text { Scheme protects RSC only and no reactive power } \\
\text { support to the grid }\end{array}$ \\
\hline 9. & $\begin{array}{l}\text { Jose and Mini } \\
(2017)\end{array}$ & $\begin{array}{l}\text { Developed a transformer-less DVR with MPC for the control } \\
\text { of grid voltage. The injection of the compensation was } \\
\text { achieved using series capacitor with dc link voltage } \\
\text { determining the maximum compensation voltage only. }\end{array}$ & $\begin{array}{l}\text { Absence of transformer do not mean no injection of } \\
\text { the zero-sequence voltage. So, the scheme is } \\
\text { limited to balanced fault. }\end{array}$ \\
\hline 10. & $\begin{array}{l}\text { Amalorpavaraj et } \\
\text { al., (2017) }\end{array}$ & $\begin{array}{l}\text { Improved control of the DVR in ensuring FRT using the } \\
\text { combined feed-forward and feedback (CFFFB)-based voltage } \\
\text { control for the implementation of the scheme. A better } \\
\text { mitigation of harmonics was recorded compared to DVR with } \\
\text { feedback control only. }\end{array}$ & $\begin{array}{l}\text { i. Not suitable when voltage sag is beyond } 0.35 \mathrm{pu} \\
\text { of the supply voltage. } \\
\text { ii. Short circuit fault requires support from } \\
\text { additional FCL. }\end{array}$ \\
\hline 11. & İnci et al., (2017) & $\begin{array}{l}\text { Developed a controller based on Missing Voltage Technique } \\
\text { (MVT) and tested it in DVR. }\end{array}$ & $\begin{array}{l}\text { No fault current limiting function to ensure the } \\
\text { safety of the DVR and by extension, the entire } \\
\text { system. }\end{array}$ \\
\hline 12. & Zhu et al., (2017) & $\begin{array}{l}\text { Presented an inductance-emulating control strategy to curb the } \\
\text { rotor inrush current due to fault thereby enhancing the LVRT } \\
\text { capability. The strategy works on making the RSC to emulate } \\
\text { inductance in order to mitigate post-fault excess current. }\end{array}$ & $\begin{array}{l}\text { Severe grid faults make the rotor inrush above the } \\
\text { inductance emulated RSC maximum value which } \\
\text { will damage the RSC and dc-link capacitor. }\end{array}$ \\
\hline 13. & $\begin{array}{l}\text { Alsmadi et al., } \\
\text { (2018) }\end{array}$ & $\begin{array}{l}\text { Proposed a new RSC control scheme for LVRT enhancement. } \\
\text { The control scheme spotlight is to mitigate the rotor side } \\
\text { voltage and current distress generated during faults. }\end{array}$ & $\begin{array}{l}\text { The control is limited by the time taken for the } \\
\text { controller to clear the fault thus the control } \\
\text { technique is not suitable for recurring faults. }\end{array}$ \\
\hline 14. & Chen et al., (2018) & $\begin{array}{l}\text { Designed a novel DVR with Energy Storage System (ESS) in } \\
\text { such a configuration that DVR is in series with DFIG terminal } \\
\text { and parallel to the dc-link between RSC and GSC. The scheme } \\
\text { represses power fluctuations }\end{array}$ & $\begin{array}{l}\text { Use of four switches in changing the operation } \\
\text { modes may lead to severe transients. }\end{array}$ \\
\hline 15. & $\begin{array}{l}\text { Sitharthan et al., } \\
\text { (2018) }\end{array}$ & $\begin{array}{l}\text { Developed a hybrid Genetic Algorithm optimized Elman } \\
\text { Neural Network (GA-ENN) controller for tuning Proton } \\
\text { Exchange Membrane Fuel Cell (PEMFC) of DVR. The } \\
\text { effectiveness of the energy storage is improved by using } \\
\text { PEMFC and the GA-ENN control made the control of the } \\
\text { customized DVR very rapid. }\end{array}$ & $\begin{array}{l}\text { The scheme has no FCL to protect the DVR and the } \\
\text { DFIG system during severe faults. }\end{array}$ \\
\hline 16. & Taher et al., (2018) & $\begin{array}{l}\text { A combination of SMC and Feedback linearization for both } \\
\text { RSC and GSC. }\end{array}$ & $\begin{array}{l}\text { Inertia of rotor will make the control to lag the } \\
\text { protection. }\end{array}$ \\
\hline 17. & Naderi et al., (2018) & $\begin{array}{l}\text { Presented a modified DC chopper for limiting fault current } \\
\text { and control of DC-link voltage }\end{array}$ & $\begin{array}{l}\text { Incapable of keeping transient overcurrent in an } \\
\text { acceptable limit }\end{array}$ \\
\hline 18. & $\begin{array}{l}\text { Harandi et al., } \\
(2019)\end{array}$ & $\begin{array}{l}\text { Presented an improved control technique for LVRT using } \\
\text { optimal demagnetization method in addition to crowbar } \\
\text { protection }\end{array}$ & $\begin{array}{l}\text { Crowbar cause short-circuit between rotor windings } \\
\text { and RSC }\end{array}$ \\
\hline 19. & $\begin{array}{l}\text { Rolan and Pedra } \\
(2019)\end{array}$ & $\begin{array}{l}\text { Presented a simplified model of DFIG under faults by } \\
\text { reducing higher order derivatives of flux. }\end{array}$ & $\begin{array}{l}\text { The assumptions made in simplification are not } \\
\text { acceptable in commercial WTs }\end{array}$ \\
\hline 20. & Le et al., (2019) & $\begin{array}{l}\text { Developed a control strategy for voltage swell while using dc- } \\
\text { chopper and crowbar for LVRT }\end{array}$ & $\begin{array}{l}\text { Use of crowbar for LVRT invalidates the } \\
\text { techniques as far as grid codes are concerned }\end{array}$ \\
\hline 21. & Zheng et al., (2019) & $\begin{array}{l}\text { Presented a resistive-type SFCL for LVRT solution in addition } \\
\text { to inductance emulating control. }\end{array}$ & $\begin{array}{l}\text { The system incurs EM torque oscillations to the } \\
\text { DFIG. }\end{array}$ \\
\hline
\end{tabular}




\section{B. State of the Art Techniques for FRT Compliance}

In view of the limitations with the reviewed works and the quest for making the DFIG based WT systems contribute to grid stability, there is need to develop a scheme for ensuring a complete FRT capability. DVR is prone to damage by large grid side fault current. This prompted the development of various topologies and control strategies of DVR with FCL capability (Jiang et al., 2018). In the event of short circuit, the FCL must protect the grid and the equipment (Bacha et al., 2008; Li et al., 2007). The FCL techniques are solid-state FCLs, superconducting FCLs, resonance-type FCLs and saturated core FCLs among others (Jiang et al., 2018). Although SFCL with additional control features incur electromagnetic torque oscillation to the entire system, the methodology of incorporating the two models must ensure limiting the oscillations for a better transient stability. Therefore, the multi-functional DVR also called DVR-FCL is proposed. The two methods of incorporating FCL to DVR are improvement of topology and optimization of control scheme. The FCLs are incorporated to protect the DVR and the DFIG

\section{REFERENCES}

Abubakar, A. S.; Y. Sha'aban; Y. Jibril; and B. Jimoh. (2018). Development of a Multiple Model Predictive Control for DFIG Based Wind Energy Conversion System. Journal of Engineering Research, 23(1), 1-12.

Abubakar, A. S., (2018). Development of a Maximum Power Point Tracking Scheme for DFIG Based Wind Turbine using a Robust Model Predictive Control. (Ph.D), Ahmadu Bello University Zaria, School of Postgraduate Studies.

Abubakar, A. S., (2019). Development of a Benchmark Controller using Gain Scheduled PI for DFIG Based Wind Turbine System. Paper presented at the ABUNEC, Zaria.

Agalar, S.; and Y. A. Kaplan. (2018). Power quality improvement using STS and DVR in wind energy system. Renewable energy, 118, 1031-1040.

Alaraifi, S.; A. Moawwad; M. S. El Moursi; and V. Khadkikar. (2013). Voltage booster schemes for fault ridethrough enhancement of variable speed wind turbines. IEEE Transactions on Sustainable Energy, 4(4), 1071-1081.

Alsmadi, Y. M.; L. Xu; F. Blaabjerg; A. P. Ortega; A. Y. Abdelaziz; A. Wang; and Z. Albataineh. (2018). Detailed Investigation and Performance Improvement of the Dynamic Behavior of Grid-Connected DFIG-Based Wind Turbines under LVRT Conditions. IEEE Transactions on Industry Applications.

Amalorpavaraj, R. A. J.; P. Kaliannan; S. Padmanaban; U. Subramaniam; and V. K. Ramachandaramurthy. (2017). Improved fault ride through capability in dfig based wind turbines using dynamic voltage restorer with combined feed-forward and feed-back control. IEEE Access, 5, 20494-20503.

Ambati, B. B.; P. Kanjiya; and V. Khadkikar. (2015). A low component count series voltage compensation scheme for DFIG WTs to enhance fault ride-through capability. IEEE Transactions on Energy Conversion, 30(1), 208-217.

Bacha, S.; D. Frey; J.-L. Schanen; E. Lepelleter; P.O. Jeannin; and R. Caire. (2008). Short-circuit limitation system from large fault currents. The requirements are fast triggering, steady-state low impedance, high fault limiting capability, fast recovery and high utilization efficiency.

\section{CONCLUSION}

A number of researches have been conducted towards improving the DFIG's FRT capability including control strategy and additional hardware devices. This work has presented a review on various techniques for FRT compliance of DFIG-based WT system. The updates in requirements necessitates the use of a scheme that will also ensure the protection of converters from damages due to short-circuit currents. For this reason, the methods of incorporating FCL to DVR through improvement of topology and optimization of control scheme are preferred. Furthermore, multi-functional compensation devices can mitigate voltage sag and swell, limit fault current and minimize power frequency variation. Finally, the improvement of functionality of the traditional DVR topology is a better alternative than installing two protective devices separately in terms of cost and complexity to the entire power system.

thanks to a series connected VSC. Paper presented at the Twenty-Third Annual IEEE Applied Power Electronics Conference and Exposition, 2008.

Benbouzid, M.; B. Beltran; Y. Amirat; G. Yao; J. Han; and H. Mangel. (2014). Second-order sliding mode control for DFIG-based wind turbines fault ride-through capability enhancement. ISA transactions, 53(3), 827-833.

Bhandare, A. M.; K. Jadhav; and M. Ghat. (2013). Performance of power coefficent and power with respect to variable wind speed. Paper presented at the 2013 International Conference on Energy Efficient Technologies for Sustainability.

Chen, L.; F. Zheng; C. Deng; Z. Li; and F. Guo. (2015). Fault ride-through capability improvement of DFIGbased wind turbine by employing a voltage-compensation-type active SFCL. Canadian Journal of Electrical and Computer Engineering, 38(2), 132-142.

Chen, Z.; J. M. Guerrero; and F. Blaabjerg. (2009). A review of the state of the art of power electronics for wind turbines. IEEE Transactions on power electronics, 24(8), 18591875.

Elshiekh, M. E.; D.-E. A. Mansour; and A. M. Azmy. (2013). Improving fault ride-through capability of DFIG-based wind turbine using superconducting fault current limiter. IEEE transactions on Applied Superconductivity, 23(3), 56012045601204.

Esch, J., (2015). High-power wind energy conversion systems: State-of-the-art and emerging technologies. Proceedings of the IEEE, 103(5), 736-739.

Fletcher, J. and Yang, J. (2010). Introduction to the doubly-fed induction generator for wind power applications Paths to sustainable energy: InTech.

Ganesh, N. and Rani, P. U. (2013). Fault-Ride Through of a DFIG Wind Turbine using a Dynamic Voltage Restorer during Symmetrical and Asymmetrical Grid Faults. 1(4), 23208945. 
Gardner, P.; G. Andrew; F. H. Lars; M. Colin; and Z. Arthouros. (2012). Wind energy-the facts: a guide to the technology, economics and future of wind power: Routledge.

Giddey, S.; S. P. Badwal; and H. Ju. (2019). Polymer Electrolyte Membrane Technologies Integrated With Renewable Energy for Hydrogen Production Current Trends and Future Developments on (Bio-) Membranes (pp. 235-259): Elsevier.

Ibrahim, A. O.; T. H. Nguyen; D.-C. Lee; and S.-C. Kim. (2011). A fault ride-through technique of DFIG wind turbine systems using dynamic voltage restorers. IEEE Transactions on Energy Conversion, 26(3), 871-882.

İnci, M.; M. Büyük; A. Tan; K. C.. Bayındır; and M. Tümay. (2017). MVT controlled voltage restorer for fault-ride through capability. Paper presented at the 10th International Conference on Electrical and Electronics Engineering (ELECO), 2017.

Jiang, F.; Y. Li; C. Tu; Q. Guo; and H. Li. (2018). A review of series voltage source converter with fault current limiting function. Chinese Journal of Electrical Engineering, 4(1), 36-44.

Jibril, Y.; G. Olarinoye; A. Abubakar; I. Abdulwahab; and O. Ajayi. (2019). Control Methods Used In Wind Energy Conversion System: A Review. ATBU Journal of Science, Technology and Education, 7(2), 53-59.

Karakasis, N.; E. Tsioumas; N. Jabbour; A. M. Bazzi; and C. Mademlis. (2018). Optimal Efficiency Control in a Wind System with Doubly Fed Induction Generator. IEEE Transactions on power electronics.

Kothari, D. and Nagrath, I. (2008). Power system engineering: Tata McGraw-Hill New Delhi.

Li, Y. W.; D. M. Vilathgamuwa; P. C. Loh; and F. Blaabjerg. (2007). A dual-functional medium voltage level DVR to limit downstream fault currents. IEEE Transactions on power electronics, 22(4), 1330-1340.

Long, T.; S. Shao; P. Malliband; E. Abdi; and R. A. McMahon. (2013). Crowbarless fault ride-through of the brushless doubly fed induction generator in a wind turbine under symmetrical voltage dips. IEEE Transactions on Industrial Electronics, 60(7), 2833-2841.

Ngamroo, I.; and T. Karaipoom. (2014). Improving low-voltage ride-through performance and alleviating power fluctuation of DFIG wind turbine in DC microgrid by optimal SMES with fault current limiting function. IEEE transactions on Applied Superconductivity, 24(5), 1-5.

Padiyar, K., (2007). FACTS controllers in power transmission and distribution: New Age International.

Pawar, S.; A. Jain; and J. Patil. (2016). Increasing low voltage ride through capability of doubly fed induction generator in wind energy transfer system during grid fault.

Pioro, I.; R. Duffey; P. Kirillov; R. Pioro; A. Zvorykin; and R. Machrafi. (2019). Current Status and
Future Developments in Nuclear-Power Industry of the World. Journal of Nuclear Engineering and Radiation Science, 5(2), 024001.

Rahimi, M. and Parniani, M. (2010). Efficient control scheme of wind turbines with doubly fed induction generators for low-voltage ride-through capability enhancement. IET Renewable Power Generation, 4(3), 242-252.

Shehu, A. F.; A. S. Abubakar; S. Musayyibi; and K. Idris. (2019). Doubly fed Induction Generator Based Wind Energy Conversion System: A Review. JOURnal of Science Technology and Education, 7(3), 145-150.

Shen, Y.-W.; D.-P. Ke; W. Qiao; Y.-Z. Sun; D. S. Kirschen; and C. Wei. (2015). Transient reconfiguration and coordinated control for power converters to enhance the LVRT of a DFIG wind turbine with an energy storage device. IEEE Transactions on Energy Conversion, 30(4), 1679-1690.

Shuaibu, M. and Abubakar, A. S. (2020). An Improved Dynamic Voltage Restorer Model for Ensuring Fault Ride-Through Capability of DFIG-based Wind Turbine Systems. ELEKTRIKA-Journal of Electrical Engineering, 19(1), 9-16.

Sitharthan, R.; C. Sundarabalan; K. Devabalaji; S. K. Nataraj; and M. Karthikeyan. (2018). Improved fault ride through capability of DFIG-wind turbines using customized dynamic voltage restorer. Sustainable Cities and Society, 39, 114-125.

Tarafdar Hagh, M. and Khalili, T. (2019). A review of fault ride through of PV and wind renewable energies in grid codes. International Journal of Energy Research, 43(4), 13421356.

Wessels, C.; F. Gebhardt; and F. W. Fuchs. (2011). Fault ride-through of a DFIG wind turbine using a dynamic voltage restorer during symmetrical and asymmetrical grid faults. IEEE Transactions on power electronics, 26(3), 807815.

Yang, L.; Z. Xu; J. Ostergaard; Z. Y. Dong; and K. P. Wong. (2012). Advanced control strategy of DFIG wind turbines for power system fault ride through. IEEE Transactions on power systems, 27(2), 713-722.

Yaramasu, V.; B. Wu; P. C. Sen; S. Kouro; and M. Narimani. (2015). High-power wind energy conversion systems: State-of-the-art and emerging technologies. Proceedings of the IEEE, 103(5), 740-788.

Zhu, D.; X. Zou; L. Deng; Q. Huang; S. Zhou; and Y. Kang. (2017). Inductance-emulating control for DFIG-based wind turbine to ride-through grid faults. IEEE Transactions on power electronics, 32(11), 8514-8525.

Zhu, R.; Z. Chen; X. Wu; and F. Deng. (2015). Virtual damping flux-based LVRT control for DFIG-based wind turbine. IEEE Transactions on Energy Conversion, 30(2), 714725 . 